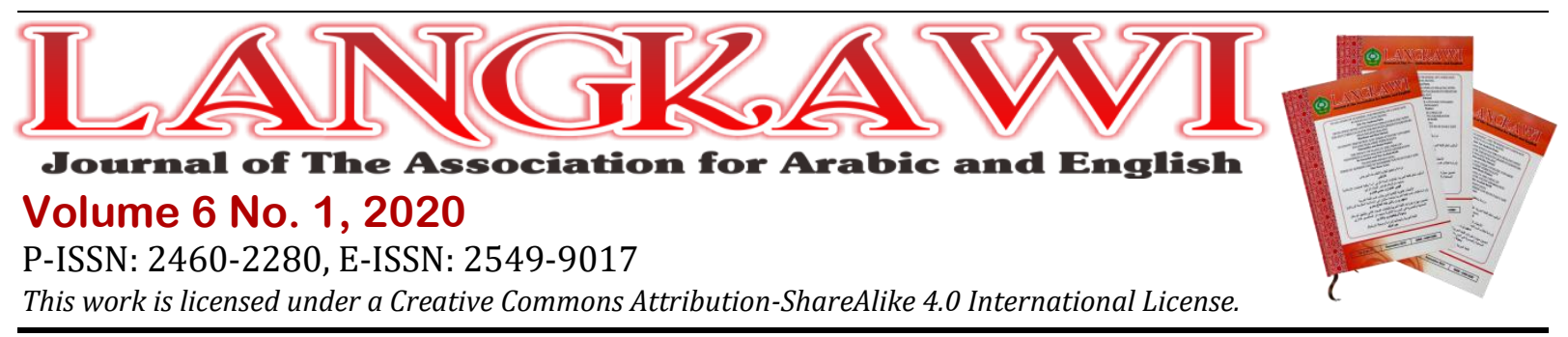

\title{
Teacher's Beliefs and Practice of Learner-Generated Material in a Flipped-Speaking Class
}

\author{
Lailatun Nurul Aniq ${ }^{*}$, Khairani Dian Anisa ${ }^{2}$, Diah Kristina ${ }^{3}$ \\ 1Universitas Sebelas Maret, Surakarta, Indonesia. Email: aniqlailatunnurul@student.uns.ac.id \\ ${ }^{2}$ Universitas Sebelas Maret, Surakarta, Indonesia.Email: khairani.dianisa@student.uns.ac.id \\ 3 Universitas Sebelas Maret, Surakarta, Indonesia. Email: diahkristina@staff.uns.ac.id \\ *corresponding author
}

\begin{tabular}{|c|c|}
\hline ARTICLE INFO & ABSTRACT \\
\hline Keywords: & The practice of the learner-centered approach (LCA) in enhancing the \\
\hline EFL, Flipped Classroom, & foreign language teaching-learning process has been broadly \\
\hline Learner-Centered & recognized. Little research, however, has disclosed how this approach \\
\hline Approach, Learner- & abilities. While learner- \\
\hline Generated Material, & is a principle of and one of the activities in \\
\hline Teacher's Belief, & ently understudied; thus, little \\
\hline Vocational High School & $\begin{array}{l}\text { researchers discuss how it applies in the EFL context. This qualitative } \\
\text { case study investigated the teacher's belief and classroom practice of }\end{array}$ \\
\hline How to cite: & $\begin{array}{l}\text { learner-generated material in a flipped speaking class. The participant } \\
\text { of the study was a teacher in a vocational high school. The instruments }\end{array}$ \\
\hline Aniq, L. N., Anisa, K. & are participant observation, semi-structured interviews, and \\
\hline D., \& Kristina, D. & documentation. The analysis indicate that the teacher's belief were \\
\hline (2020). Teacher's Belief & mostly consistent with her classroom practices, i.e., beliefs about \\
\hline and Practice of Learner & learning objectives, teaching modeling, and procedure of learner- \\
\hline Generated Material in a & generated material, teaching resources, classroom management, \\
\hline Flipped-Speaking Class. & $\begin{array}{l}\text { teacher's role, students' role, and assessment. Nevertheless, few } \\
\text { discrenancies existed e. teachers' beliefs about teaching-learning }\end{array}$ \\
\hline wi: Journal of The & $\begin{array}{l}\text { discrepancies existed, e.g., teachers beliefs about teaching-learning } \\
\text { resources and classroom procedures. The present study recommends }\end{array}$ \\
\hline$h, 6(1), 29-40$ & $\begin{array}{l}\text { that teachers, especially those new to LGM, follow the current findings } \\
\text { to recognize the aspects within LGM under LCA, and understand how }\end{array}$ \\
\hline DOI: & to practice these methods. The implication of the study is this research \\
\hline http:/ & the Indonesian ELT context by providing a new \\
\hline $332 / 1 \mathrm{kw} . v 6 \mathrm{i1} .16$ & perspective of the learner-centered approach through technology. \\
\hline
\end{tabular}

\section{Introduction}

The paradigm shift of the "teacher-centered" approach to the "learner-centered" or "student-centered" approach happens worldwide (Bremner, 2019). The learnercentered approach (LCA) is frequently considered as an example of "best practice" and has been acknowledged by many global organizations, e.g. UNESCO (Schweisfurth, 2015). Learner-centered approach (LCA) is a learning approach highlighting students' needs over those of other involved individuals, such as administrators and teachers in the education system (Al-Zu'be, 2013). LCA has found its way in English Language Teaching (ELT). English for Specific Purposes (ESP) is an example of the implementation of learner-centered approach since all teaching practices are administered based on specific learners' specific needs (Javid, 2015). 
In the Indonesian context, teaching English in vocational education, particularly at the secondary level, should be considered as an ESP program (Widodo, 2016). A vocational high school (VHS) is one of the educational institutions responsible for producing competent workers. They can adjust to the changes in need of the society as the effect of the dynamic international economy with the support of the Indonesian demographic bonus (Soenarto, Amin, \& Kumaidi, 2017). Besides, the Act of the Republic of Indonesia No. 20 of 2003 on National Education System article 15 states that vocational education is a secondary education program for preparing students to a skill. The statement above infers that vocational high school (VHS) should provide students with specific skills or should train them to have professional expertise in a particular field so that they have adequate competence to face global competition.

For this reason, the English material in VHS should be different from the English content in general senior high school. Moreover, it should fulfil students' needs in each department. The needs in each of the departments should be met as English used in speaking and writing vary from one context to another (Hutchinson \& Waters, 1986). One department has specific terms (registers), which may not be found in other departments. However, in the context of vocational education in Indonesia, the fact reveals that the 2013 Curriculum (K13) of VHS and general schools have the same English learning materials. Hence, the existing material cannot fulfil the students' needs. More surprisingly, VHS students are required to have an internship, which lasts for months. During the course, they still need to learn the material from the textbook (personal information, November 6, 2019). This condition complicates students in learning English.

2013 Curriculum for VHS states that job interview is one of the materials in 12th grade of VHS. By mastering the material, students are expected to be ready to face the work field. VHS students learn how to do a good job interview. However, there is some interference in learning job interview. First, there is a limitation of time in practising job interviews for all students. Second, some examples of the job interview in the handbook do not meet students' needs. As technology develops, the teacher and students can utilize the technology for teaching-learning job interview processes, e.g., students can use the internet to find job interview material as they need, and the teacher can creatively choose an alternative teaching method using technology for betterment result.

With the infusion of technology in a classroom, it is possible for teachers to utilize technology in their learning. Flipped learning is an alternative way to integrate technology in teaching. Flipped learning is a pedagogical model which invert the instruction delivery and homework accomplishment (Webb, Doman, \& Pusey, 2014). Meaning that, in a traditional classroom, students do their homework at home and learn the material at school. However, they learn the material at home by studying written or spoken materials given by teachers. They also actively participate in teacherled instructional activities at school in a flipped classroom. Flipped learning promotes a more interactive classroom atmosphere (Piehler, 2014; Flynn, 2015; Halili, Razak, \& Zainuddin, 2015). As a consequence, it encourages students to take more part in activities involving cognitive intelligence, student-student interaction, and level of collaboration. 
However, Sabah \& Du (2018) find that in the implementation of a learnercentered approach, the students' interaction is limited. Learner-generated material (LGM) is a way that enables students to have more peer interaction through discussion. Moreover, learner-generated material is a viable option as an in-class activity in a flipped classroom (Bakla, 2018). The reasoning for this option is that the students could have more advantages if they become material producers (Cockrum, 2013; Engin 2014). By giving space to create a material, students can design the material which meets their needs.

The teachers' decision to apply a technique or approach were mainly influenced by the teachers' beliefs. Teachers' belief systems are manifested on the goals and values teachers hold on the content and the process of teaching, and their understanding of the systems in which they work within it (Richard and Lockhart, 1994). They add that it comes from experience as language learners, work experience, practice, personality factors, education-based or research-based principles, and principles from an approach or a method. Richard and Lockhart (1994) state that beliefs can be categorized into beliefs about English and beliefs about learning. Fauziati (2017) mentions belief about learning cover the best English learning style, learners' attitude, learning strategies, learners' role, teachers' role, teaching method, teaching resources, effective teaching, classroom management, and assessment.

Several researchers have researched the learner-centered approach. Some researchers investigate learner-generated instruction (Bakla, 2012; Chen \& Lui, 2012). Other researchers look into interaction among students in LCA (Chen, 2017; Chin \& Clarck, 2013; Edstrom, 2015), belief and practice in LCA (Bremmer, 2019; Hutchinson \& Waters, 1987; Javid, 2015), and contrast teacher-centered approach and learnercentered approach (Al Zu'be, 2013; Yamagata, 2018). In addition, some researchers analyzed the development of teaching EFL in Indonesia (Aradhanawaty \& Madjid, 2016; Soenarto, Amin, \& Kumaidi, 2017; Widodo, 2006).

Although many studies have shown the use of flipped-learning and learnergenerated material, little is known about the learner-generated in a flipped classroom in a VHS. The learner-generated material is considered as a viable way to meet the students' needs and allow more student-student interaction. Moreover, the flipped classroom enables students to learn at their own pace. Since the issues relating to defective material, technology integration, and lack of student-student interaction have not been examined, it means that the issues have not been resolved. Therefore, the novelty of this research is the vocational students are taught using a flippedlearning model utilizing learner-generated material. Thus, this study aims at investigating the teacher's belief and classroom practice of learner-generated material in a flipped speaking class on job interview material.

\section{Method}

To answer the problem question, this research was designed as a qualitative study. Qualitative research illustrates a real case and involves significant contextual conditions relevant to the case (Yin, 2017). The intrinsic study examines unique participant(s), i.e., individuals, groups, or events, and concentrates on the case itself (Creswell, 2007). In the collective case study, the researchers choose one issue or multiple case studies to illustrate the issue and its setting. In this study, researchers 
conducted a case study of the teacher's beliefs and practice of learner-generated material in a flipped speaking class on job interview material.

To select the case and gather information about the case, the researcher needs to establish a rationale for his or her purposeful sampling strategy (Yin, 2017). Researchers selected the participant since the participant could purposefully inform an understanding of the research problem and the central phenomenon in the study. The participant of the study was a professional vocational high school teacher. She had more than ten years teaching experience. The participant was coded as V, and this was a pseudonym.

The research was conducted from October 2019 until November 2019 in the academic year of 2019/2020. This research carried out in an Indonesian vocational high school. The researchers visited the school eight times to collect the data. The identity of the participant and the identity of vocational high school was a pseudonym due to ethical considerations.

To provide an atmosphere of cooperation, trust, and shared respect is critical for the researcher to get precise information (Fraenkel \& Wallen, 2008). During the data collection, the researchers developed a positive relationship with the participant by honouring the participant's demands, interests, and efforts in the study. This research had three concerns, i.e., beliefs, classroom practices, and the interrelationship between theories and practices. Therefore, three techniques used to collect the data are interviews, classroom observations, and documentation.

The researchers analyzed all data collected by the ways proposed by Strauss and Corbin's theory (1998). First, the researchers carried out thickly interviews for data collection that supplemented other forms of data collection, i.e., observation and document analysis. Second, the researchers employed related theories to make the interview guideline and observation checklist so that the teacher revealed the necessary information. Third, the researchers continuously compared the collected information. Fourth, the information transformed as data collection and analysis progressed. Fifth, after analyzing the data progressively, researchers presented the data into findings and discussion.

\section{Findings and Discussion}

Based on the data obtained from the research, the results explore the reflection of the English teacher's beliefs and practices in some aspects, i.e., the reflection of English teacher's beliefs in learning objectives, teaching modeling, the procedure of learner-generated material, teaching resources, classroom management, teacher's role, students' role, and assessment. The findings were based on the analysis of the data taken from interviews with the teacher, the observation in the speaking class, and the documents from the teacher.

\subsection{Learning Objectives: Acquiring Students' Need and Desire}

Since the teacher's focus on the students' needs and desires, it seemed that the classroom appeared so learner-centered. The light issues might become indications, e.g., students' performances of the job interview and peer discussion to get the materials students wished. It was in line with Bakla (2012) and Chen \& Lui's (2012) findings that learners get access and composed the material that they wanted in learner-generated material. She appeared to provide students with choosing the topic 
of the job interview and doing peer feedback among them. Another indication showing that the learning objectives were planned to acquire students' need and desire was the willingness of the teacher to do whatever that motivates the students to study and participate in the classroom. It is specifically apparent in the following quote:

"For me, there are elementary steps on teaching job interviews are. First, making students curious about what I teach to them, engaging. Second, I should focus on one thing, usually, providing the explicit material in the first meeting and the last meeting to activate the students through the task in making material and performing it in the classroom. Next, I attempt to involve my students in the classroom by creating interview scenarios in class, and students practice it because this is speaking class. Students have to speak. As a teacher, I monitor them in performing job interview correctly and as much as possible." $(V, 2019)$

In brief, interview, observation, and documentation guided to the impression that this teaching-learning process was not the conventional teacher-centered in which students just sat and listened to the teacher's explanation on their seats. Instead, it was speaking classroom where the students directed by the teacher through fascinating activities based on their motivation and competences; given options about what they were interested in to study; and involved in active learning activities.

\subsection{Teaching modeling: Requiring Student's Prior Knowledge and Performance}

The teacher often induced prior knowledge to promote student's critical thinking skills. This indication was in line with Bremer (2019), Chen (2017), and Chen \& Lui's (2012) findings that learners' prior knowledge was an elemental feature in LCA. It could be happened through giving the questions after the teacher told the material clues that would be discussed in every meeting. Another indication was the teacher enhanced the modeling method in teaching speaking. The modeling method was made through students' performances. During the meeting of job interview speaking lessons, students were always provided the challenging learning activities from the teacher as the following quote:

"I've recognized that students can learn the lessons more when they are active instead of passive. Consequently, I want to activate students by making the interview scenarios as real as possible in class when they are required to speak actively." (V, 2019)

In some interview sessions, the teacher stated that her primary teacher's role was knowledge provider. However, she sometimes was unable to educate students well, owing to her limited knowledge about something, e.g., the use of technology. In consequence, she tried to solve this weakness. This is particularly apparent in the following quote:

"I often have less confidence, and sometimes I am not sure about something that I have to teach because I also do not have much knowledge about a certain job, and I do not master well ... but I try my best by learning knowledge early." $(V, 2019)$

\subsection{The Practice of Learner-Generated Material in Flipped Classroom}

The teacher recognized a flipped classroom as inverting the activity traditionally conducted at the school into the business conducted outside the classroom. Based on the observation, the teacher initiated the teaching activity by providing some materials related to job interview with the students through social media. The students were asked to learn the structure and lexico-grammatical features 
of job interviews. The students also watched some job interview videos provided by the teacher. When the students came to the class, they read and watched the videos briefly, and at times the teacher delivered succinct explanations about the material. The teacher asked the students to look for a job vacancy advertisement in various sources and create a job interview video for the position offered at home in pairs. The students were freed to choose their groupmate. The video should: (1) be well-ordered, (2) use appropriate registers and lexico-grammatical features, and (3) represent job interview in a real-world context.

The video, then, sent to the teacher through social media. In the class, the teacher presented the video and invited the group to explain it to their peers. Then, the teacher encouraged the students to give comments for the video submitted. The teacher created this activity as she wanted to foster the student's creativity and create materials that meet their needs. This procedure was closely similar with Bakla (2012) presented about the implementation of learner generated material. This is also particularly apparent in the following quote:

"I think that the provided material for this topic is too broad. I don't think that the material can cover my students' needs. By creating their own material, I hope that my students can select the topic that suits their needs. Through this process, they can understand the material deeper and develop their creativity" $(V, 2019)$

However, there was a discrepancy between belief and classroom practice. The teacher informed in the interview that she had prepared for the class well, while in a specific case, there was a technical problem that the teacher did not anticipate. The observation result showed that the teacher did not anticipate the technical problem that might emerge in playing the video. Moreover, some of the videos presented did not employ appropriate dictions, as quoted below:

"I appreciate what my students have made, but some of them missed some points in their videos. They did not use the right words in their videos which decrease the usefulness of the material." (V, 2019)

\subsection{Teaching-Learning Resources: Establishing Resources-Based Learners}

A major theme that emerged from this research was teaching-learning resources. It disclosed that the teacher provided resources-based learners since the teacher assumed that it was beneficial as an in-class activity. In addition, the students seemed to like the idea of choosing and producing their learning materials through the internet, and it was helpful for them. The indication of the activities on which students sought learning-teaching resources was expressed clearly in the following quote from the teacher:

"...I surely assure that they'll study. Students could learn while choosing and organizing material, and at the same time, they did it enthusiastically." (V, 2019)

The use of the word "assure" indicated that she believed about the instructional benefits of providing practice session. The tone of the word that she stated was her sure confirmation since it voiced outspoken and believable. To investigate the results further, the researchers specifically asked what the teacher assumed was different in practice or not. In response to this question, the teacher stated the opinion that voiced too hypothetical: 
"This situation might happen since you learn by doing research and learn by revising what you have chosen and prepared. You learn the subject while researching the internet for preparing the learning material and continuously revising it." (V, 2019).

Nevertheless, her statements appeared to be quite standard responses indicated by several regular terms, e.g., doing research, feeling of joy, and progressive revising, were common keywords stated as the reference of the advantages of learner-generated material. As the students created learner-generated material by using modern educational tools, the involvements of and the students' concerns about learnergenerated material were found based on interview and classroom observation. The teacher assumed that designing learner-generated material was enjoyable. However, there were some discrepancies. There were some underlying problems as indications, e.g., lack of students' internal motivation to complete the tasks. Besides, it could be considered learner-generated material was a very time-consuming activity. It was contradicted with Al Zu'be (2013) and Yamagata's (2018) findings that time was not influenced by the practice of LCA rather than TCA.

\subsection{Classroom Management: Appointing Controlled Talkative Class}

The teacher consistently gave extra opportunities for students to speak English. From the data, it was marked that students, through learner-generated material in the flipped classroom, had been engaged to be talkative. Regarding controlled talkative class, the concept was informed verbally. The teacher explained some interaction, the teacher to students, students to students, and students to the teacher. According to the teacher, the primary purpose that she emphasized the goal of the high interaction was for students to recognize what they understood and did not remember what they could learn instead of their assumptions.

During the teaching-learning process, the teacher permitted noise in the classroom, but the teacher monitored the students' activities and gave time allocation. Students could interact as time permits. The teacher admitted that most of the students were able to develop their speaking skills. Nevertheless, she explained how it took time for students to promote self-efficacy to speak. He added how a significant effort within the student happened from the passive listening learners to active speaking learners. From her experience, this attempt had to do for students to engage in the classroom efficiently. This is the following quote from the teacher:

"Language lesson, for me, must be noisy. I always design to allow my students to speak aloud. However, I always ensure that the noise can't affect other classrooms." (V, 2019)

\subsection{Teacher's Role: Representing Several Teacher's Role}

The direction of class interaction among students and the teacher, i.e. the teacher to a student, a student to the teacher and a student to another student was an indication that the teacher was not dominant. Despite boss teaching, the data from observation and document analysis showed that the role of a teacher as a facilitator and a motivator. During the class interaction between the teacher to student in each meeting, the teacher's job was a facilitator that eased the students to develop their knowledge and abilities in teaching-learning process. A facilitator in this context meant a teacher did some activities, e.g. preparing the example of material, doing brainstorming, theorizing grammar correctly, modeling how to pronounce basic 
interview words well, organizing the students, and asking some questions to trigger the students' critical thinking.

The class interaction between students and the teacher happened when the students almost replied to all of the things the teacher had delivered. It started from listening and understanding teachers' explanations, imitating how to pronounce well of interview vocabularies, researching to compose the material, being prepared in answering all the teacher's questions, and doing student to student interaction. The interaction among students happened when they designed the material, made the interview scenario and performed the job interview script between students in the speaking classroom. They had to cooperate in giving the best in their collaborating. It was crystal clear in the following quote:

"Honestly, I don't think deeply about my role in the classroom. I don't say teacher's role is not important for me. But despite using the same role in every condition, I prefer to be flexible." (V, 2019)

She also adopted the role of a knowledge transmitter, especially at the beginning of the meeting. She consistently explained, questioned, drilled, and gave examples. Then, she employed other roles in different situations, i.e., she carried out communicative activities. Other roles were knowledge resource, activity organizer, guide, supporter, helper, group organizer, monitor, assessor, and controller. Nevertheless, these roles employed rarely and infrequently.

\subsection{Students' Role: Transforming Active Learners}

It was clear that students' role indicated to be more learner-centered than traditional-oriented. Then, some roles appeared, e.g., initiator, investigator, knowledge constructor, and group worker. Those roles performed in some particular situations. It was found from the observations that the classroom was both a place for teaching and a place for learning. However, the teacher should transmit knowledge directly to students in the beginning meeting, while they constructed knowledge after they understood what they had to do. Therefore, students also played the role of knowledge recipients. It indicated during the teacher's explanations, students became listeners, and answered the teacher's questions consciously when the teacher did not ask one of them.

When the students had opportunities to work in groups or individually, some of them became teaching assistants or tutors for others. They had the responsibility of guiding and helping each other. Also, students' $4 \mathrm{C}$ competence was promoted since they learn to work together, help each other, and think critically. It was also observed that the students assumed different roles and became more active when the teacher used communicative activities along with pair or group work because they interacted with others, performed a job interview scenario, and made the material together. It was in line with the teacher's statement as follows:

"Flipped classroom and learner-generated material seem to provide students opportunities to express themselves. They can maximize what they know and what they think. Indeed, students also have more time in doing conversation with others." $(V, 2019)$ 


\subsection{Assessment: Utilizing Peer Feedback}

The student-student interaction occurred not only in composing the learnergenerated material but also in providing comments on the material presented. The teacher invited the students to deliver oral feedback about job interview videos showed. The teacher did not set any rubric for students as their guidelines for commenting on the videos. The teacher facilitated autonomy for the students to give their opinion about the videos presented. Moreover, the teacher wanted to train students' critical thinking skills, as quoted in the following statement:

"I give my students a chance to comment on the videos presented. I want to know what they are thinking about the video. This activity also activates their critical thinking skills. I do not want them just to watch and wait for my comment." (V, 2019)

The utilization of peer feedback as the assessment tool served as the media for the students to have more interaction. Through this activity, the students could learn from each other more about the material. Moreover, the feedback provided by the students might be more meaningful as they knew which aspect should be included to meet their needs.

Most teacher's belief aspects were consistent with classroom practice. Those aspects were learning objectives, teaching modelling, the procedure of learnergenerated material, teaching resources, classroom management, teacher's role, students' role, and assessment. The teacher's belief findings that collected from interview were relevant to the researchers observed in the classroom that strengthened documentation. It was revealed that the teacher consciously and unconsciously practised them in the classroom. These findings were verified by other research that found a positive correlation between the teacher's beliefs and the practices (Bakla, 2012; Chen \& Lui's, 2012; Chen, 2017; \&Bremer 2019). Our investigation further grew our perspective of this relationship among teacher's beliefs and practices as we found more in-depth information from each aspect.

We found that different motives underlaid $\mathrm{V}$ and participants from previous studies guided them to demonstrate what she believed. For instance, V claimed that students might have a better score if they had a high motivation to do and participate in learning activities. Hence, she allowed students to choose material as their needs and desire. This was contradicted with Bakla's (2018) research that revealed the underlying reason was to improve students' higher-order thinking skills.

Next, this study disclosed that those teacher's beliefs have shaped teachers' practices, e.g. the selection of priorities for teaching-learning resources and the way the learners established resources $\left(\mathrm{Zu}^{\prime}\right.$ be, 2013). Some related studies totally agreed that EFL teachers with learner-centered belief practice preferred implementing learner-generated material that focused on the learners' need and desire (Bakla, 2012; \& Chen \& Lui's, 2012); needed students' prior knowledge and performance (Bremer, 2019, Chen, 2017; \& Chen \& Lui's, 2012); and facilitated autonomy for the students to do peer feedback (Engin, 2014). The consistency between the teachers' beliefs and the practices turned evident when learner-generated material was applied in teaching. Still, teachers had the motives differently based on their beliefs about learning objectives, teaching modelling, procedure of learner-generated material, teaching resources, classroom management, teacher's role, students' role, and assessment. 
However, the researchers found that there were discrepancies between teachers' beliefs and classroom practices. The teacher claimed that she was wellprepared for their teaching activity, yet she did not fully anticipate for some technical problems. Moreover, the teacher claimed that the LGM was an enjoyable technique for students. However, some students might lack internal motivation to complete the tasks as it was time-consuming. Hence, in some parts, i.e. the teaching-learning resources and the practice of learner-generated material, researchers found partial consistency between teachers' beliefs and classroom practice. These inconsistencies have been explained with contextual factors, e.g., the characteristics among students were different. The teachers claimed that they did several specific actions, yet the researchers did not find the consistency between teachers' beliefs and classroom practice. Furthermore, the teacher was likely to make choices involving pedagogical knowledge, technological knowledge, and technological pedagogical knowledge based on their situation and experience.

\section{Conclusion}

This study examined a vocational high school teacher's beliefs and classroom practices of learner-generated material in a flipped speaking class. The study results indicated that most of the teacher's beliefs were in line with the classroom practices, i.e. beliefs about learning objectives, teaching modeling, the procedure of learnergenerated material, teaching resources, classroom management, and teacher's role, students' role, and assessment. However, this study identified the differences between teacher beliefs and classroom practice in terms of teaching-learning resources and procedures. Despite the light contradiction of the teacher's beliefs and classroom practice, this study suggests that the process in implementing learner-generated material presented in this study can be a guideline for teachers, particularly those new to learner-generated content.

Despite its limitation in the given context, the result of this study suggests that learner-generated material, which is in the umbrella of the learner-centered approach, can be an alternative way to teach English. Teachers should adopt learner-generated material with its benefits in their English classes when teachers focus on the material that students need and want. Further study may investigate the students' voices of the application of this instruction. This research contributes to the ELT context by providing a new perspective on the learner-centered approach using technology.

\section{References}

$\mathrm{Al} \mathrm{Zu}$ 'be, A. F. M. (2013). The difference between the learner-centered approach and the teacher-centered approach in teaching English as a foreign language. Educational Research International, 2(2), 24-31.

Aradhanawaty \& Madjid. (2016). The teaching of English oral communication in the application of curriculum 2013. Langkawi, 2(1), 63-82.

Bakla, A. (2018). Learner-generated materials in a flipped pronunciation class: A sequential explanatory mixed-methods study. Computers $\mathcal{E}$ Education, 125(10), 1438.

Bremmer, N. (2019). From learner-centered to learning-centered: Becoming a 'hybrid' practitioner. International Journal of Educational Research, 97(1), 53-64.

Chen, G \& Lui, P. (2012). Comparisons of learner-generated versus instructor- 
provided multimedia annotations. The Turkish Online Journal of Educational Technology, 11(4), 72-83.

Chen, W. (2017). The effect of conversation engagement on L2 learning opportunities. ELT Journal, 71(3), 329-340.

Chin, A \& Clark, D. B. (2013). Learning through collaborative argumentation. New York: Taylor \& Francis.

Cockrum, T. (2013). Flipping your English class to reach all learners: Strategies and lesson plans. New York: Routledge.

Creswell, J. W. (2007). Qualitative inquiry and research design: choosing among five approaches (2nd Edition). United States of America: SAGE Publications, Inc.

Edstrom, A. (2015). Triads in the L2 classroom: Interaction patterns and engagement during a collaborative task. System, 52(2), 26-37.

Engin, M. (2014). Extending the flipped classroom model: Developing second language writing skills through student-created digital videos. The Journal of Scholarship of Teaching and Learning, 14(5), 12-26.

Fauziati, E. (2017). Teaching English as a foreign language (TEFL II): Principle and practice. Surakarta: Era Pustaka Utama.

Flynn, A. B. (2015). Structure and evaluation of flipped chemistry courses: organic \& spectroscopy, large and small, first to third year, English and French. Chemistry Education Research and Practice, 16(2), 198-211.

Frankel, J. P. \& Wallen N. E. (2008). How to design and evaluate research in education. New York: McGraw-Hill Companies, Inc.

Halili, S. J., Razak, A., R., \& Zainuddin, Z. (2015) Enhancing collaborative learning in flipped classroom. Australian Journal of Basic and Applied Sciences, 9(7), 147-149.

Hutchinson, T., \&Waters, A. (1987). English for specific purposes: A learne-centered approach. New York: Cambridge University Press.

Javid, C. Z. (2015). English for specific purposes: Role of learners, teachers and teaching methodologies. European Scientific Journal. 11(20), 17-34.

Piehler, C. (2014, December 3). FLN shares its four pillars of flipped learning. The Journal. https://thejournal.com/articles/2014/03/12/fln-announces-formal-definitionand-four-pillars.aspx? $\mathrm{m}=1$

Richards, J. C., \& Lockhart, C. (1994). Reflective teaching in second language classrooms. Cambridge: Cambridge University Press.

Sabah, S. \& Du, X. (2018). University faculty's perceptions and practices of student centered learning in Qatar: Alignment or gap?. Journal of Applied Research in Higher Education, 10(4), 514-533.

Schweisfurth, M. (2015). Learner-centered pedagogy: Towards a post-2015 agenda for teaching and learning. International Journal of Educational Development, 40, 259266.

Soenarto, S., Amin, M. M., \& Kumaidi. (2017). An evaluation of vocational high schools in Indonesia: A comparison between four-year and three-year programs. Research and Evaluation in Education, 3(2), 106-113.

Strauss, A., \& Corbin, J. (1998). Basic of qualitative research: Techniques and procedures for developing grounded theory. Thousand Oaks, CA: SAGE Publications, Inc.

Webb, M., Doman, E., \& Pusey, K. (2014). Flipping a Chinese university EFL course: What students and teachers think of the model. The Journal of Asia TEFL, 11(4), 
Lailatun Nurul Aniq, Khairani Dian Anisa, Diah Kristina: Teacher's Beliefs and Practice of Learner-Generated Material in a Flipped Speaking Class

53-87.

Widodo, H. P. (2006). Approaches and procedures for teaching grammar. English Teaching: Practice and Critique, 5(1), 122-141.

Yamagata, S. (2018). Comparing core-image-based basic verb learning in an EFL junior high school: Learner-centered and teacher-centered approaches. Language Teaching Research, 22(1), 65-93.

Yin, R K. (2017). Case study research and applications: Design and methods (6 $6^{\text {th }}$ Edition). Thousand Oaks, California: Sage Publications, Inc. 